This item was submitted to Loughborough's Research Repository by the author.

Items in Figshare are protected by copyright, with all rights reserved, unless otherwise indicated.

\title{
Introduction: Towards more inclusive and comparative perspectives in the histories of geographical knowledge
}

PLEASE CITE THE PUBLISHED VERSION

http://dx.doi.org/10.1080/00330124.2017.1288572

\section{PUBLISHER}

(c) Taylor \& Francis

\section{VERSION}

AM (Accepted Manuscript)

\section{PUBLISHER STATEMENT}

This work is made available according to the conditions of the Creative Commons Attribution-NonCommercialNoDerivatives 4.0 International (CC BY-NC-ND 4.0) licence. Full details of this licence are available at: https://creativecommons.org/licenses/by-nc-nd/4.0/

\section{LICENCE}

CC BY-NC-ND 4.0

\section{REPOSITORY RECORD}

Jons, Heike, Janice Monk, and Innes M. Keighren. 2019. "Introduction: Towards More Inclusive and Comparative Perspectives in the Histories of Geographical Knowledge”. figshare.

https://hdl.handle.net/2134/23578. 
Please cite the version of the article to be published in The Professional Geographer http://www.tandfonline.com/loi/rtpg20

Introduction: Towards more inclusive and comparative perspectives in the histories of geographical knowledge

\author{
Heike Jöns
}

Loughborough University

Janice Monk

University of Arizona

Innes M. Keighren

Royal Holloway, University of London

Accepted version uploaded to The Professional Geographer

$1^{\text {st }}$ December 2016 
A quarter of a century ago, Mona Domosh (1991a; 1991b) launched a powerful call for a feminist historiography of geography. That call was received extremely critically by David Stoddart (1991), at that time one of the chief historians of geography within and beyond the United States (see Stoddart 1986). Domosh argued for the incorporation of Victorian women explorers into histories of geography because of their distinct contribution to the production of geographic knowledge - a contribution made despite the fact that most of them had been excluded from geography's academic departments and learned societies. Drawing inspiration from social scientific critiques of discourses in the natural and technical sciences (e.g., Harding 1986), Domosh stressed that the subjective nature of women explorers' travel narratives meant that they had been wrongly ignored as a consequence of the objectified "standards of 'scientific' geography" (1991a, 96) that had been constructed by male gatekeepers whose views mirrored contemporary, largely skeptical attitudes towards women's intellectual pursuits.

Stoddart's response to Domosh's call was blunt: most of the Victorian women explorers she discussed were "long forgotten" and, as such, the "case for a feminist historiography of geography has not been made" (Stoddart 1991, 484). Stoddart's assessment, and his insistence that the absence of women in his own book On geography and its history (Stoddart 1986) "reflects the historical reality of the academic development of the subject" (Stoddart 1991, 484), suggests that he might not have fully recognized why such an account would need to be critiqued in light of Donna Haraway's convincing characterization of masculinist scientific objectivity as "the god-trick of seeing everything from nowhere" (1988, 176). According to Haraway (1988), knowledge can only be produced from a specific perspective because it is always embodied within physically confined bodies and artefacts and hence is situated and partial. This means that if geographical knowledge was primarily (re)produced from the 18th to the 20th centuries by white, largely middle-class men who 
learned to disregard the intellectual capabilities of women, there was indeed a profound danger of excluding half of humanity from the project of geography (Monk and Hanson 1982).

Haraway (1988) also stressed that the production of academic knowledge can only strive for incomplete but accountable embodied objectivity because there are no such things as absolute objectivity and ultimate truth. This argument provides a powerful justification for incorporating into histories of geography those contributions to geographical knowledge that were both motivated by “purely personal” (Stoddart 1991, 485) reasons and written by individuals who were "not in any realistic disciplinary sense geographers" (Stoddart 1991, 484). As Livingstone (1992) and Heffernan (2003) have convincingly argued, any narrow understanding of geography as a neatly defined objective discipline has thus itself been fundamentally flawed.

More than two decades after this controversial exchange, it is evident that feminist geographical scholarship has been pivotal for “writing women's lives, voices, stories, and experiences" (Domosh and Morin 2003, 262) into geography and for pointing to the ongoing need to create a less partial and more complete historiography of geography and associated fields (Maddrell 2015). Parallel to historical and sociological studies on the role of women in the scientific community (e.g., Zuckerman and Cole 1975; Rossiter 1982; Zuckerman et al. 1991; Dyhouse 1995; Etzkowitz et al. 2000; Panayotidis and Stortz 2015), the focus of geographical research has been on the colonial and postcolonial geographies of female travel writers (e.g., Blunt 1994; Blunt and Rose 1994; McEwan 2000; Thomas 2004; Ryan 2006; Morin 2008); on female academic geographers (e.g., Zelinsky 1973; McDowell 1979; Zelinsky et al. 1982; McDowell and Peake 1990; Monk 1998, 2006; Sack 2004; Keighren 2010; Kaplan and Mapes 2016; Maddrell et al. 2016); and on female professional 
geographers working in other profit, non-profit, and public institutions (e.g., Monk 2003, 2004; Maddrell 2008, 2009).

Attention has also turned to the implications for gender representation of changing labor markets and disciplinary orientations. Research by Pujol, Garcia Ramon, and Ortiz (2012) with contemporary Spanish geographers, for example, suggests that the increasing orientation towards technical methods and environmental themes appears to be having differential influences on careers and life paths of men and women geographers because this has decreased the proportion of women in academic geography. These authors contrast contemporary men and women geographers with earlier generations whose research interests, they show, were oriented more towards the humanities and who engaged more explicitly in the preparation of school teachers. Moreover, a growing number of geographical studies has scrutinized women's contributions to mobile geographical practices and knowledges beyond the confines of disciplinary boundaries (e.g., Domosh and Seager 2001; Uteng and Cresswell 2008; Thomas 2009; Jöns 2011; DeLyser 2011).

The articles in this focus section engage with these topical debates by renewing Domosh's (1991a) call for more inclusive perspectives in the historiography of geography and by arguing that such a project requires comparative research perspectives that consider related disciplines and sub-disciplines, institutional and cultural contexts, employment sectors, periods of time, and/or axes of social difference, such as gender, age, class, race, nationality, sexual orientation, migration status, and other discursive constructions. Accordingly, we agree with Heffernan's $(2003,19)$ assessment that there is "no single, unified discipline of geography today and it is difficult to discern such a thing in the past" because "geography, whether defined as a university discipline, a school subject or a forum for wider debate, has always existed in a state of uncertainty and flux". From this perspective, the production of geographical knowledge is constituted by a diverse set of practices, 
discourses, and materialities that do not necessarily require a focus on professionally certified geographers but can include a variety of previously hidden, unfamiliar, and mundane aspects of its creation and dissemination (e.g., Heffernan and Medlicot 2002; Lorimer and Spedding 2002; Lorimer 2003; Thomas, 2004; Driver and Jones 2009; Driver 2013; Keighren 2016).

The following contributions are situated at the intersection of feminist histories of geography and feminist historical geographies in the 20th century. Innes M. Keighren examines the practices and discourses of multidisciplinary women travelers, members of the London-based Lyceum Club, who lobbied for the inclusion of women into the Royal Geographical Society from 1904 to 1913; Heike Jöns analyses the travels, careers, and contributions of early female academics in a new era of professionalizing disciplines by comparing the practices and biographies of female and male academic travelers from different disciplines in the University of Cambridge from 1926 to 1955; and Janice Monk investigates the careers, support networks, and contributions of university-trained, professional female geographers working in U.S. government agencies from 1915 to the 1970s. The emphasis of this focus section is, therefore, on the role of women in producing and disseminating geographical knowledge in and from different institutional, disciplinary, and sectoral contexts.

Keighren's article reveals a significant and previously undocumented part of women's early 20th-century contributions to British geography through attention to the activities of the Lyceum Club — an organization that was founded for women members in London in 1904 and that (through the activities of its Geographical Circle) paved the way for the professional recognition of women geographers through admission to the Royal Geographical Society from 1913 onwards. He specifically highlights the complex influence of inclusive and exclusionary practices in women's quests to gain access to exclusive academic circles. On the one hand, the club's membership was fairly exclusive in that it catered only for relatively 
high-status women and mainly for those with independent financial means - a fact that demonstrates how important financial security was in enabling women's contributions to the production of geographical knowledge in the early 20th century. On the other hand, the privileged women of the club's Geographical Circle employed multiple inclusive practices in order to become a part of exclusive professional geographical circles, for example, by inviting male geographers to give lectures and by stressing that membership was, in theory, open to women of both small and large incomes.

Moreover, Keighren applies three inclusive perspectives that link the history of geography to the wider fin-de-siècle movements of women's rights, internationalism, and the formation of academic disciplines. First, he tells the story of women's lobbying for inclusion into professional geographical circles; second, he stresses the international nature of the Lyceum Club, which had been envisioned (and subsequently developed) as a network of international branches of clubhouses; and third, he discusses the interdisciplinary and intersectoral nature of membership in the club. Founded by a novelist, this club saw writers, journalists, travelers, and anthropologists participating in original geographical work through adventuresome travel — a fact that demonstrates how diverse scholarly and creative practices contributed equally to the production of geographical knowledge in the early 20th century.

Jöns's article analyses the academic travels, professional careers, and intellectual contributions of early female academics across disciplines in the University of Cambridge from 1926, the year in which women were first appointed to university positions in Cambridge, to 1955, the end of the first postwar decade. She stresses the need to compare similarities and differences not only among different women but also between female and male academics in order to conduct truly contextualized feminist studies and thus prevent stereotyping of gendered behavior. Her comparative analysis shows that the academic performance of early female academics was, in many ways, comparable to that of their male 
peers but that the geographies of their travels were less extensive and that they remained largely excluded from personal knowledge networks because women focused more on using periods of leave for research purposes and rarely attended conferences. This relative absence from conference networking presents a specific reason for the long invisibility of women in geography and other disciplines despite often substantial writings, a contradiction that inspired Domosh's call for a feminist historiography of geography in the first place.

Jöns's analysis of selected biographies characterizes these early female academic travelers as highly privileged and academically outstanding individuals who benefitted from an upper-middle-class background, academic family members, dual-career relationships, nonfamilial academic patronage, and superior educational capital when developing their academic potentials against powerful discursive constructions about traditional gender roles and inferior female scholarship. While these women academics were affiliated with distinct university disciplines, they still contributed to the creation of geographical knowledge through their travels and writings, even if this knowledge was not always the main product but a by-product of their academic practices. Jöns's inclusive perspective on the histories of geography thus does not only refer to female academic geographers in the university but also to early female academics in other disciplines who produced and disseminated academic and geographical knowledge through their overseas travels.

Monk's article extends her work on the contributions of women to American geography in schools, colleges, and universities by studying their employment in the U.S. government sector. In the 1970s, when women were struggling for permanent positions in universities, this sector employed proportionally twice as many women members of the Association of American Geographers than did academia. Based on a life-course approach, Monk outlines the diverse range of personal and professional circumstances that facilitated early professional careers of women from the 1910s onwards - at a time when American 
society was dominated by the ideal of the male breadwinner and much more unsympathetic to education for women at the university level and to women's participation in the professional labor market than in the later decades of that century.

Common factors that encouraged government careers of female geographers were financial necessity and hardship, the demand for qualified personnel during periods of war or other crises, the resistance in many universities to employing female faculty, and existing networks among alumni and geographers. These pioneering female geographers benefitted mainly from the support, encouragement, and contacts of mostly but not only male professors, mentors, family, and friends, thus exposing the striking paradox that female professional careers in geography and elsewhere have not only been hindered (Traweek 1999) but also been supported by old boys' networks among university academics and alumni. Without the support of male mentors, none of the professional careers Monk discusses would probably have happened, especially because her case studies illustrate that there were not many female role models and gatekeepers around until later decades of the 20th century.

Even if recent research has underlined the important role of female role models and female encouragement for women's academic careers (e.g., Etzkowitz et al. 2000; Jöns 2011; Kaplan and Mapes 2016), this important finding suggests a shift in focus from gendered networks to individuals, or from examining the inclusion of women into geography and other professions against the interests of unsympathetic men and old boys' networks to studying why and how some male and some female gatekeepers have been more supportive of women than others. Given that Clark University and the University of Chicago provided important platforms for launching the government careers of female geographers in the early and mid20th century, further research could usefully compare the support of women in different geography departments, as has been examined for recent decades by Kaplan and Mapes 
(2016). It could also analyze which sub-disciplinary fields of geography have, and for what reasons, facilitated more or less academic and other professional careers of women because "comparative histories could reveal practices that have deterred or supported women" (Monk 2004, 10).

In conclusion, the three papers in this focus section have identified women who contributed significantly to the production and circulation of geographical and other academic knowledges in different institutional contexts in the United Kingdom and the United States during the 20th century. From this perspective, Stoddart's (1991) remarks about the historical contributions of women to geography appear, in hindsight, to be the result of both a narrow understanding of geography and a lack of research rather than the justified forgetting of unimportant individuals. Such controversial judgments problematize the topical issue of research evaluation by exposing the partial perspective of all qualitative and quantitative assessments because they are shaped by the biographies and interests of individual academics and their networks (e.g., Haraway 1988; Berg 2001; Keighren 2016).

In the early 21 st century, when more than two fifths of U.S. and British academics are female, it is important to remember that gender inequalities go beyond the mere presence of women in academia. Keighren's study observes that female geographers had to be seen to be not merely as good as, but actually better than their male counterparts if they wanted to be included into male-dominated professional circles. This fact resonates with Jöns's finding that the careers of early female academics in Cambridge were almost all based on outstanding academic achievements. Even in the context of academic promotion in U.S. universities during the late 20th century, recent research has pointed out that the professional achievements of women were still judged more harshly by both men and women (Loeb 2006), confirming that the support of early career female academics by women at more advanced career stages is also not always guaranteed. On the whole, it seems that what 
Rossiter (1993) termed the 'Matilda effect' in science - the systematic under-recognition of women's contributions to academic knowledge production, ranging from the denial of female authorship via the attribution of women's ideas to male colleagues and collaborators to the lack of rewards for women academics — is still a frequent practice in 21 st century academia.

Moreover, recent studies suggest that women often remain underrepresented at advanced career stages, as well as in the natural and technical sciences, and disadvantaged in regard to their salary, family status, and workload, as well as their departmental, universitywide and international networking practices (Etzkowitz et al. 2000; Loeb 2006; Jöns 2011; European Commission 2016; Maddrell et al. 2016). For example, women have less often combined an academic career with having a partner and children than have men and, if they do so, are affected by the discriminating trend that having a family tends to promote men's academic careers but hinder that of women (Ginther and Kahn 2006). Further studies on the historical contexts and path-dependencies of female careers and the contributions of women to geographical and other academic knowledge in different places and periods of time therefore remain of prime importance in countering persisting gender inequalities and facilitating social change. Furthermore, we suggest that conducting more comparative studies on men and women, using both quantitative and qualitative research methods, in similar ways as Etzkowitz et al.'s (2000) comprehensive life course perspective on women academics' 'cumulative disadvantage' and the resulting duality of male and female scientific worlds has done, would improve our understanding of how financial resources, personal and professional networks, and academic achievements have impacted in similar or different ways on the careers and contributions of women and men in various historical and geographical contexts.

On the one hand, it seems to be of prime importance to compare the manifold barriers and support mechanisms that women and men-as well as individuals of different ages, races, sexual orientations, nationalities, disciplines, and other categorizations of social 
difference - have experienced at different times and in different places (Valentine 2007). On the other hand, it is pivotal to acknowledge that gender inequality and discrimination "are context-dependent, could be the other way around, and thus go far beyond direct gender relationships" (Jöns 2011, 189). Most existing studies also focus on heterosexual norms of partnering and family life and thus research would benefit from the inclusion of the full diversity of heterosexual, homosexual, bisexual, and asexual identities, relationships, and life course trajectories into studies of geographers' careers and the production and circulation of geographical knowledge (for the academy more generally, see D’Emilio 1992; Talburt 2000).

In the light of such manifold research desiderata, we argue, finally, that the future of a vibrant feminist historiography of geography and an equally flourishing feminist historical geography, as powerful tools for making the production of academic knowledge less partial, resides on two main goals: 1) continuously diversifying inclusive and comparative research perspectives and 2) identifying and exploring diverse archives that more fully capture the contributions made by those heretofore wrongly ignored in geography's histories.

\section{References}

Berg, L. D. 2001. Masculinism, emplacement, and positionality in peer review. The Professional Geographer 53 (4): 511-21.

Blunt, A. 1994. Travel, gender and imperialism: Mary Kingsley and West Africa. New York: Guilford.

Blunt, A., and G. Rose. 1994. Introduction: Women's colonial and postcolonial geographies. In Writing women and space: Colonial and postcolonial geographies, ed. A. Blunt and G. Rose, 1-25. London: Guildford Press. 
DeLyser, D. 2011. Flying: Feminisms and mobilities - crusading for aviation in the 1920s. In Geographies of mobilities: Practices, spaces, subjects, ed. T. Cresswell and P. Merriman, 83-96. Aldershot: Ashgate.

Domosh, M. 1991a. Toward a feminist historiography of geography. Transactions of the Institute of British Geographers 16 (1): 95-104.

1991b. Beyond the frontiers of geographical knowledge. Transactions of the Institute of British Geographers 16 (4): 488-90.

Domosh, M., and J. Seager. 2001. Putting women in place: Feminist geographers make sense of the world. New York: Guildford Press.

Domosh, M., and K. M. Morin. 2003. Travels with feminist historical geography. Gender, Place and Culture 10 (3): 257-64.

Driver, F. 2013. Hidden histories made visible? Reflections on a geographical exhibition. Transactions of the Institute of British Geographers 38 (3): 420-35.

Driver, F., and L. Jones. 2009. Hidden histories of exploration: Researching the RGS-IBG collections. London: Royal Holloway, University of London, in association with the Royal Geographical Society (with IBG).

Dyhouse, C. 1995. No distinction of sex? Women in British universities, 1870-1939. London: UCL Press.

D’Emilio, J. 1992. Making trouble: Essays on gay history, politics, and the university. London: Routledge.

Etzkowitz, H., C. Kemelgor, and B. Uzzi. eds. 2000. Athena unbound: The advancement of women in science and technology. Cambridge: Cambridge University Press.

European Commission. 2016. She Figures 2015. Luxembourg: Publications Office of the European Union. 
Ginther, D. K., and S. Kahn. 2006. Does science promote women? Evidence from academia 1973-2001. NBER Working Paper No. 12691. Cambridge, MA: National Bureau of Economic Research.

Haraway, D. 1988. Situated knowledges: The science question in feminism and the privilege of partial perspective. Feminist Studies 14 (3): 575-99.

Harding, S. G. 1986. The science question in feminism. Milton Keynes: Open University Press.

Heffernan, M. 2003. Histories of geography. In Key concepts in geography, ed. S. L.

Holloway, S. Rice, and G. Valentine, 3-22. London: SAGE.

Heffernan, M., and C. Medlicot. 2002. A feminine atlas? Sacagewea, the suffragettes and the commemorative landscape in the American west, 1904-1910. Gender, Place \& Culture: A Journal of Feminist Geography 9 (2): 109-31.

Jöns, H. 2011. Transnational academic mobility and gender. Globalisation, Societies and Education 9 (2): 183-209.

Kaplan, D.H, and J.E. Mapes. 2016. Where are the women? Accounting for discrepancies in female doctorates in U.S. Geography. The Professional Geographer 68 (3): 427-35.

Keighren, I. M. 2010. Bringing geography to book: Ellen Semple and the reception of geographical knowledge. London: I.B.Tauris.

- Forthcoming. History and philosophy of geography I: The slow, the turbulent, and the dissenting. Progress in Human Geography.

Livingstone, D. N. 1992. The Geographical Tradition. Oxford: Blackwell.

Loeb, J. W. 2006. The status of female faculty in the U.S.: Thirty-five years with equal opportunity legislation Management Revue 17 (2): 157-80.

Lorimer, H. 2003. Telling small stories: Spaces of knowledge and the practice of geography. Transactions of the Institute of British Geographers 28 (2): 197-217. 
Lorimer, H., and N. Spedding. 2002. Excavating geography's hidden spaces. Area 34 (3): 294-302.

Maddrell, A. 2008. The 'Map Girls': British women geographers' war work, shifting gender boundaries and reflections on the history of geography. Transactions of the Institute of British Geographers 33 (1): 127-48.

- 2009. Complex locations: Women's geographical work in the UK, 1850-1970. Oxford: John Wiley \& Sons.

Maddrell, A., Strauss, K., Thomas, N. J., and Wyse, S. 2016. Mind the gap: Gender disparities still to be addressed in UK Higher Education geography. Area 48 (1): 4856.

McDowell, L. 1979. Women in British geography. Area 11 (2): 151-54.

McDowell, L., and L. Peake. 1990. Women in British geography revisited: Or the same old story. Journal of Geography in Higher Education 14 (1): 19-30.

McEwan, C. 2000. Gender, geography and empire: Victorian women travellers in West Africa. Aldershot: Ashgate.

Monk, J. 1998. The women were always welcome at Clark. Economic Geography 74 (1): 1430.

2003. Women' worlds at the American Geographical Society. Geographical Review 93 (2): $237-57$.

- 2004. Women, gender, and the histories of American Geography. Annals of the Association of American Geographers 94 (1): 1-22.

- 2006. Changing expectations and institutions: American women geographers in the 1970s. The Geographical Review 96 (2): 259-77.

Monk, J., and S. Hanson. 1982. On not excluding half of the human in human geography. Professional Geographer 34 (1): 11-23. 
Morin, K. M. 2008. Frontiers of femininity: A new historical geography of the nineteenthcentury American West. New York: Syracuse University Press.

Panayotidis, E. L., and P. Stortz. eds. 2015. Women in higher education, 1850-1970: International perspectives. New York: Routledge.

Pujol, H., M. D. Garcia Ramon, and A. Ortiz. 2012. El profesorado universitario de geografía en España y sus trayectorias profesionales: una mirada de género. Boletín de la Asociación de Geógrafos Españoles 59: 323-44.

Rossiter, M. W. 1982. Women scientists in America: Struggles and strategies to 1940. Baltimore: Johns Hopkins University Press.

—. 1993. The Matthew Matilda effect in science. Social Studies of Science 23 (2): 32541.

Ryan, J. R. 2006. 'Our home on the ocean': Lady Brassey and the voyages of the Sunbeam, 1874-1887. Journal of Historical Geography 32 (3): 579-604.

Sack, D. 2004. Experiences and viewpoints of selected women geomorphologists from the mid-20th century. Physical Geography 25 (5): 438-52.

Stoddart, D. 1986. On geography and its history. Oxford: Blackwell.

- 1991. Do we need a feminist historiography of geography - and if we do, what should it be? Transactions of the Institute of British Geographers 16 (4): 484-87.

Talburt, S. 2000. Subject to identity: Knowledge, sexuality, and academic practices in higher education. Albany, NY: SUNY Press.

Thomas, N. J. 2004. Exploring the boundaries of biography: The family and friendship networks of Lady Curzon, Vicereine of India 1898-1905. Journal of Historical Geography 30 (3): 496-519. 
Traweek, S. 1999. Pilgrim's progress: Male tales told during a life in physics. In The science studies reader, ed. M. Biagioli, 525-42. New York: Routledge.

Uteng, T. P., and T. Cresswell. eds. 2008. Gendered mobilities. Aldershot: Ashgate.

Valentine, G. 2007. Theorizing and researching intersectionality: A challenge for feminist geography. The Professional Geographer 59 (1): 10-21.

Zelinsky, W. 1973. Women in geography: A brief factual account. The Professional Geographer 25 (2): 151-65.

Zelinsky, W., J. Monk, and S. Hanson. 1982. Women and geography: A review and prospectus. Progress in Human Geography 6 (3): 317-66.

Zuckerman, H., and J. R. Cole. 1975. Women in American Science. Minerva 13 (1): 82-102.

Zuckerman, H., J. R. Cole, and J. T. Bruer. 1991. The outer circle: Women in the scientific community. New York: W.W.Norton. 


\section{Author Bio}

HEIKE JÖNS is Reader in Human Geography in the Department of Geography at Loughborough University, Loughborough, Leicestershire, LE11 3TU, United Kingdom. E-mail: h.jons@1boro.ac.uk. Her research focusses on transnational academic mobility and the geographies of knowledge production, the historical geographies of the university, and triadic thought.

JANICE MONK is Research Professor in the School of Geography and Development and Research Social Scientist Emerita at the University of Arizona, Tucson AZ 85721. E-mail jmonk@email.arizona.edu. Her research interests include international and historical perspectives on feminist geography, higher education, and changing social conditions of Aboriginal communities in Australia.

INNES M. KEIGHREN is Reader in Historical Geography in the Department of Geography at Royal Holloway, University of London, Egham, Surrey, TW20 0EX, United Kingdom. Email: innes.keighren@rhul.ac.uk. He has research interests in geography’s disciplinary and discursive histories, in book history, and in the history of science. 